\title{
MILLING CAPACITY AND SUPPLY COMPETITION IN SUGAR-ETHANOL INDUSTRY IN SÃO PAULO, BRAZIL
}

\author{
Walter BELIK ${ }^{1}$ \\ Bruno Benzaquen PEROSA ${ }^{2}$ \\ Sérgio Rangel Fernandes FIGUEIRA ${ }^{3}$ \\ Andrea KOGA-VICENTE ${ }^{4}$
}

\begin{abstract}
After the deregulation of the sugar and alcohol sector, the decision on the location and scale of processing units was transferred to the private sector. Given the competition, the search for raw materials increased substantially and became the key variable in determining the viability of plants. The neoclassical microeconomics indicates that the increase in capacity is the result of a decision to maximize the outcome of firms, especially considering the industrial economies of scale. However, the theory of industrial organization, raises the possibility of the decision on the installed capacity be affected by the competitive strategy of the firm, leading to raise barriers to entry. Thus, plants located in regions with greater competition for sugarcane would work with higher levels of idle capacity, as deterrent to entry of new units. Using techniques of geo-referencing, the research shows that in the traditional sugarcane areas, the installed capacity in recent years far exceeds the availability of raw material. Thus, it is unlikely that plants installed in these regions are operating in an "optimal" level grinding. Gains force the hypothesis that excess capacity has the role to impose barriers to entry despite the reduced efficiency of the plants.
\end{abstract}

Key words: Brazil. Sao Paulo State. Bioenergy. Sugarcane. Agro-industry.

\footnotetext{
1 Instituto de Economia / Universidade Estadual de Campinas. Docente. Cidade Universitária Zeferino Vaz, s/n, 13083-970 - Campinas, SP. E-mail: belik@unicamp.br.

2 Instituto de Economia/ Universidade Federal de Uberlândia. Docente. Center Shopping Santa Mônica, 38408902 - Uberlândia, MG. E-mail: brperosa@gmail.com

3 Departamento de Economia Rural / Universidade Estadual Paulista. Docente. Via de Acesso Prof. Paulo Donato Castellane, s/n, 14884900 - Jaboticabal, SP. E-mail: sergio-figueira@uol.com.br.

4 CEPAGRI / Universidade Estadual de Campinas. Pós-Doutoranda. Cidade Universitária Zeferino Vaz, s/n, 13083-970 - Campinas, SP. E-mail: andrea.kvicente@gmail.com
} 


\section{Resumo}

\section{Capacidade de moagem e competição no abastecimento na indústria sucroalcooleira em São Paulo, Brasil}

Com a desregulamentação do setor sucroalcooleiro, a decisão de localização e escala das unidades processadoras foi transferida para o setor privado. Dado o aumento da concorrência, a disputa pela matéria-prima também aumentou substancialmente e o seu acesso se transformou na variável chave para a determinação da competitividade das usinas. A microeconomia neoclássica indica que o aumento da capacidade instalada é resultado de uma decisão de maximização do resultado das firmas, considerando principalmente as economias industriais de escala. Contudo, a teoria da organização industrial, levanta a possibilidade da decisão sobre a capacidade instalada ser afetada pela estratégia competitiva da firma, visando elevar barreiras à entrada. Desse modo, usinas localizadas em regiões com maior competição por cana-de-açúcar trabalhariam com níveis superiores de capacidade ociosa, como forma de dissuasão para entrada de novas unidades. Utilizando técnicas de georreferenciamento a pesquisa mostra que nas áreas canavieiras tradicionais, a capacidade instalada nos últimos anos é muito superior a disponibilidade de matéria-prima. Dessa forma, é pouco provável que as usinas instaladas nessas regiões estejam operando em um nível "ótimo" de moagem. Ganha força a hipótese de que a capacidade ociosa tem o papel de impor barreiras à entrada a despeito da redução da eficiência das usinas.

Palavras-chave: Bioenergia. Cana-de-açúcar. Agroindústria.

\section{INTRODUCTION}

The state of São Paulo is the largest producer of sugarcane as well as processed sugar and ethanol in Brazil. Sugarcane production rose from 50.4 million tons in to São Paulo state and 110 million tons in Brazil in the 1983/84 harvest to 304.2 million tons and 558 million tons, in São Paulo state and Brazil, respectively in the 2011/12 harvest (UNICA, 2013). The state, therefore, expanded from a $45.8 \%$ share of the national harvest in the $1983 / 84$ to a $54.5 \%$ share in $2011 / 12$.

This impressive growth in recent decades may be largely credited to public policies that sought to improve the efficiency of the sugar and alcohol industry in Brazil and São Paulo. Ferreira and Alves (2009) reported that by the end of the 1960s, the Brazilian government put forth the first plan to rationalize the sugarcane agroindustry, eradicating small plants, which were deemed economically inefficient. By raising the efficiency of Brazilian production, the government aimed to make Brazil a major sugar exporter. Unfortunately, because it was unable to achieve being a preferential market for the United States and the European Economic Community, Brazil's plans were frustrated.

Due to the first global oil crisis from 1973-1974, the Brazilian government launched the National Alcohol Program, seeking to promote the use of alcohol as an automotive fuel, initially by mixing it with gasoline. After the second global oil crisis in 1979, the alcohol fuel program was expanded in the Brazilian market through the sale of automobiles powered exclusively by hydrous alcohol. Baccarin et al. (2009) points out that in parallel to fostering demand for alcohol fuel in the Brazilian market, public policies were executed to expand the supply of alcohol in Brazil and improve the industry's productivity, stimulating an increase in the average size of plants and seeking to eliminate those plants deemed as technologically outdated and inefficient. In the 1980 s the Brazilian alcohol fuel program suffered a setback as a result of a drop in oil prices on the international market summed to a rise in sugar prices and of the state fiscal crisis. Thus, PROALCOOL, the Brazilian alcohol fuel program, went into a decline. It was only in the late 1990s that the Brazilian alcohol industry saw an opportunity to 
export alcohol to other countries, which from this point forward would be called ethanol, the same denomination used in the USA. As of 2003, another demand arose for ethanol in the Brazilian market with flex-fuel cars, powered by ethanol and/or type $\mathrm{C}$ gasoline. An even greater expansion of the sugar and alcohol industry was seen in this period (2003-08). This expansion was possible by an increase of sugarcane fields (ALVES et al., 2009; CORREA, 2013), and due to changes in the mills organization (MACEDO, 2011).

However, starting in 2008, favorable expectations for the industry began to wane for a series of reasons. At the international level, Brazilian ethanol was unable to reach desired international markets because of import duties and other types of nontariff barriers (usually under the argument of socio-environmental sustainability) as well as due to the very scarcity of the supply produced nationally (PEROSA, 2012). The global economic crisis of 2008 and the diminished momentum among countries to cut greenhouse gases also cut into favorable outlooks regarding Brazilian ethanol exports and lowered investments made in Brazil to grow ethanol and sugar production. In Brazil, keeping the price of gasoline at levels supposedly less attractive to the industry inhibited investments in the sector.

From an institutional standpoint, the sugar and alcohol industry was regulated from 1933 to 1990 by the Instituto do Açúcar e do Álcool (Institute of Sugar and Alcohol or IAA), which controlled every economic aspect of this agro-industrial complex. The IAA in particular was concerned with the possibility that plants and distilleries could expand their milling capacity, which could create a no holds barred competition for raw material, thus driving up sugar and alcohol production costs. When the government stopped regulating these matters, private actors began to experience the freedom to outline their own corporate strategies. From 1990 on, the milling capacity was decided by private investors, not suffering any kind of control by the state.

When a new investment cycle started in 2003 motivated by the increasing potential of sales for ethanol on the international market, mainly to the US and Europe, there was no form of state control in place. In addition, the international sugar market was also boosted by importers such as Russia and China. Finally, in the Brazilian domestic market, a new generation of flex-fuel cars encouraged good expectations regarding the investment. As a result of these great expectations, the sugar-ethanol sector was invaded by great corporations from the agricultural and oil sector (BUNGE, CARGIL, SHELL, BP, etc.) (MACEDO, 2011). During this period, mergers and acquisitions happened, resulting in in the formation of large conglomerates such as Raízen, a joint venture between the COSAN (a traditional sugarcane producer in Brazil) and Shell. In this process, large private investments have been made, geared towards expanding the production capacity at sugar and alcohol producing plants.

This process of growth in the sugar and alcohol industry reflected in the conversion of lands to cultivate sugarcane in the entire São Paulo state. These areas were previously used for grain and livestock chains. In this sense, regions such as Presidente Prudente and Araçatuba are emblematic, with sugar and alcohol activities having already begun using significant mechanization in the agricultural phase (PEROSA et. al, 2013). In the industrial sector, the number of sugar and alcohol plants rose from 137 in the 1999/00 harvest to 169 in the 2008/09 harvest. In this expansion process in the sugar-based energy industry, there was a notable increase in the scale of sugarcane milling in São Paulo plants.

Research by Baccarin et al. (2009), Ferreira et al. (2009) and Vian and Belik (2003) sought to assess the strategies of domestic and international groups in the unregulated sugar and alcohol industry in the first decade of the 2000s. These studies indicate economic and industrial concentration in the last years, where larger companies were able to lower administrative costs and gain an edge in bargaining to acquire raw material and services in production. 
In the current context of deregulation, it is extremely important to analyze how the private investments have affected the competition for sugarcane and the efficiency of sugarcane mills. Since there is an overlap of plants in the same area, idle capacity may rise as well as the costs for acquiring raw materials. In all cases, the allocation inefficiency affects the mills and increases costs of production of sugar and ethanol.

The main goal of this paper is to analyze how the recent expansion of sugarethanol sector São Paulo state have affected sugarcane competition and the efficiency of sugarcane mills. This strategy will be taken by following two specific objectives: (1) build a map covering the competition for cane sugar in the state of São Paulo, (2) conduct a numerical analysis comparing the milling capacity with cane available in 15 major producing regions of the state. This study is divided into 5 sections, starting with this introduction. Section 2 introduces a review of literature on sugarcane expansion in the state of São Paulo and the change in the average scale of the state's plants. Next, a methodological strategy for creating the maps is presented. Section 4 provides the results and discussion of the study. Lastly, the final considerations are discussed, followed by bibliographic references.

\section{LITERATURE REVIEW}

\section{Economies of scale, barriers to entry and idle capacity}

In a market environment, industries adopt competitive strategies to survive and expand the appreciation of their capital in the face of potential competitors. The industry defines its strategies considering specific characteristics of the sector, and the strategy of competitors, as well. The economy of scale is an important means to reduce costs and achieve competitive advantages. Economy of scale means that a reduction on average costs generated by higher production level of a plant (PINDYCK; RUBINFELD, 2002). According to Kupfer; Hasenclever, (2002), the gain may come from three sources: 1) The gain of specialization-the greater quantity of product produced, the greater will be the labor division, and more workers and machines may become specialized; 2) The technical indivisibility of industrial equipment - it is hardly ever possible to buy precisely the proper equipment with the proper size to produce the required amount; the possible underuse of equipment means a future increase of production; 3) Geometric Economies - the geometric properties of processing units, typical of chemical and metallurgical processes. The product of these units tends to be proportional to the volume of the unit, while the cost associated with the production is proportional to the surface area of the processing units.

Researchers of industrial organization identify the existence of economies of scale as one of the reasons for market concentration in a sector (BAIN, 1959). Therefore, the gain in economies of scale triggers a selection of few industries able to survive in the market. To enable gains of scale, the industries' challenge is to increase the supply of inputs and the productive capacity. The inappropriate supply of inputs could force the industry to operate with idle capacity or increase the cost of purchasing inputs and raw materials at a greater distance. In both cases, as costs increase, competitive advantages decrease. However, according to the literature, large industries may plan idleness for competitive reasons, so not all idleness is considered a problem that will trigger unexpected rises in costs (PENROSE, 1962).

Thus, the existence of planned idle capacity is an important tool for the strategy of large-scale capitalist industry, mainly in sectors with homogenous products. Steindl (1952) provided empirical evidence of the strategy used by large industries to maintain 
planned idle capacity. Yet, economic and technical factors are the reasons for planned idleness. Regarding technical factors associated with indivisibility, production cannot expand gradually. Regarding economic factors, uncertainty about the future behavior of demand explains why the industry expands its production capacity ahead of demand growth, preventing the entry of new competitors.

\section{Expansion of sugarcane in the state of São Paulo}

The substantial expansion that the Brazilian sugar-based energy sector underwent from 2000 to 2010 had an impact on agricultural production in São Paulo, which accounts for over $58.2 \%$ of Brazil's sugarcane production" ${ }^{5}$. The "visible" change in the state's rural landscape testifies to the profound change in land use, which was previously geared towards other crops like oranges, livestock and traditional food crops such as beans and corn. The industry's growth resulted in deep changes to the economy of these new regions. The replacement of sugarcane for crops is the most apparent facet of this sugarcane expansion process into areas where before soy, corn and beans were grown, in addition to being used for livestock activities. In this sense, there is a noticeable increase in the proportion of sugarcane in both traditional as well as new regions. This process can be seen (Graph 1 ) by considering the fifteen regions that produce more sugar cane in the state. These regions accounted for approximately $76.4 \%$ of the state production of sugarcane in 2012 .

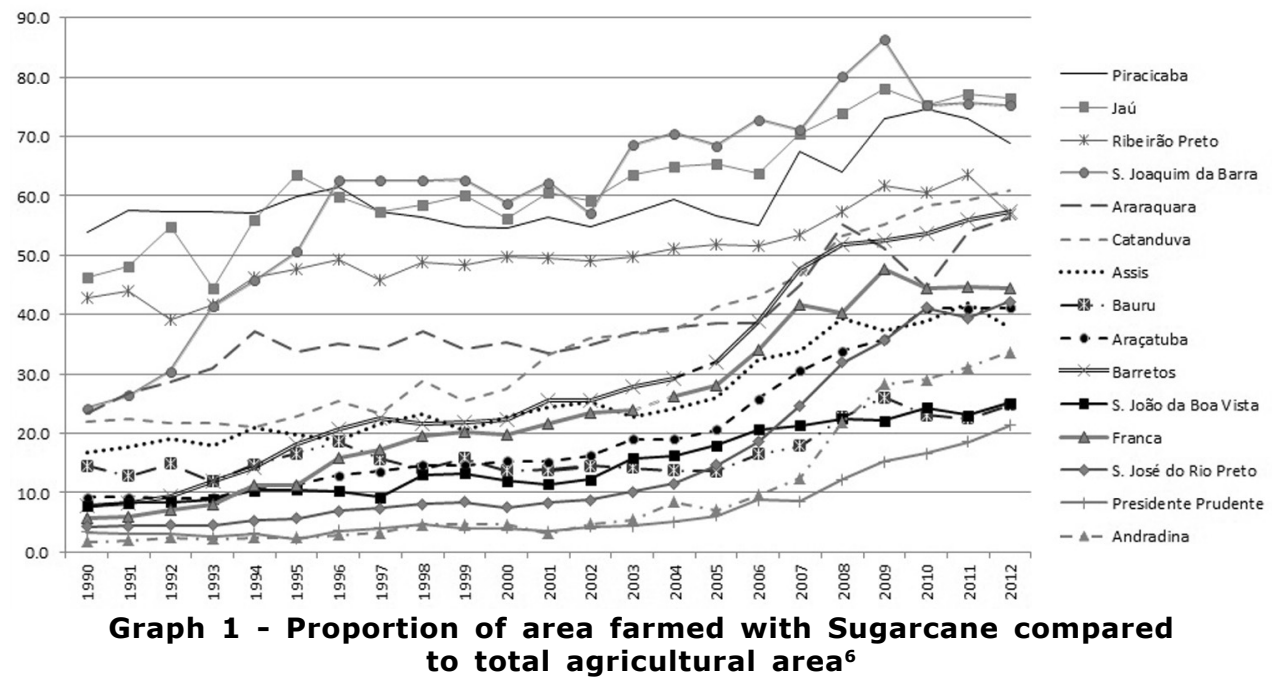

Source: drafted using data from the Ministry of Agriculture (MAPA) and Brazil's Geography and Statistics Institute (IBGE).

\footnotetext{
5 Data on sugarcane harvested by from PAM (Municipal Agriculture Survey or PAM), IBGE (2011).

6 Methodology for calculating agricultural area: was found using: (i) geoprocessing: the layers of total municipal area were used, minus bodies of water (rivers and reservoirs), environmental protection areas (MAPA data) and areas with a slope of over 45\%; (ii) areas occupied by farming and livestock establishments (IBGE), lands not suitable for agricultural activities (ponds, swamps and marshes) (IBGE), areas used for aquaculture (IBGE), and land that is not usable for agricultural activities (eroded land, salt-affected soils or desertification) (IBGE) were subtracted from the area resulting from the previous process.
} 
As seen in graph 1 , in recent years, in both Jaú and S. Joaquim da Barra, more than $70 \%$ of the area available for farming and ranching are being used for sugarcane crops. On the other hand, in the regions of S. João da Boa Vista and Presidente Prudente, sugarcane farming has been taking place on a more modest scale, but at an intense pace of growth. In the last five years, these two region shave doubled their share of areas farming sugarcane compared to the total available for farming and ranching activities. Considering the availability of vast areas with low occupation, yet with great potential for production in these regions, it seems evident that growth of this crop is far from reaching its limits.

\section{Change in the milling capacity of São Paulo plants}

The process of expansion of units in the state of São Paulo has had a direct impact on the average milling capacity of these units. Castro et al. (2010) looked at changes in the number of plants and the scale of milling at units for the 99/00 and 08/ 09 harvests. The authors found an increase from 137 to 169 plants in the state and a higher scale of milling. They found a reduced number of plants whose milling capacity was below 1 million tons per harvest, a figure which fell from 59 units in the 99/00 harvest to 36 units in the 09/09 harvest, with the share of these types of plants in the state dropping from $43.1 \%$ in the $99 / 00$ harvest to $21 \%$ in the $09 / 09$ harvest (see Graph 2). At the other extreme, there was a jump in the number of units with a capacity to mill over 5 million tons per harvest, going from 3 to 7 units in the period, raising the share in the number of these plants in the state from $2.2 \%$ to $4 \%$. Furthermore, there was notably higher growth in the number of plants with a capacity to mill between 2 and 3 million tons per harvest in this period, increasing from 13 to 42 units, going from a $9.5 \%$ to a $25 \%$ share.

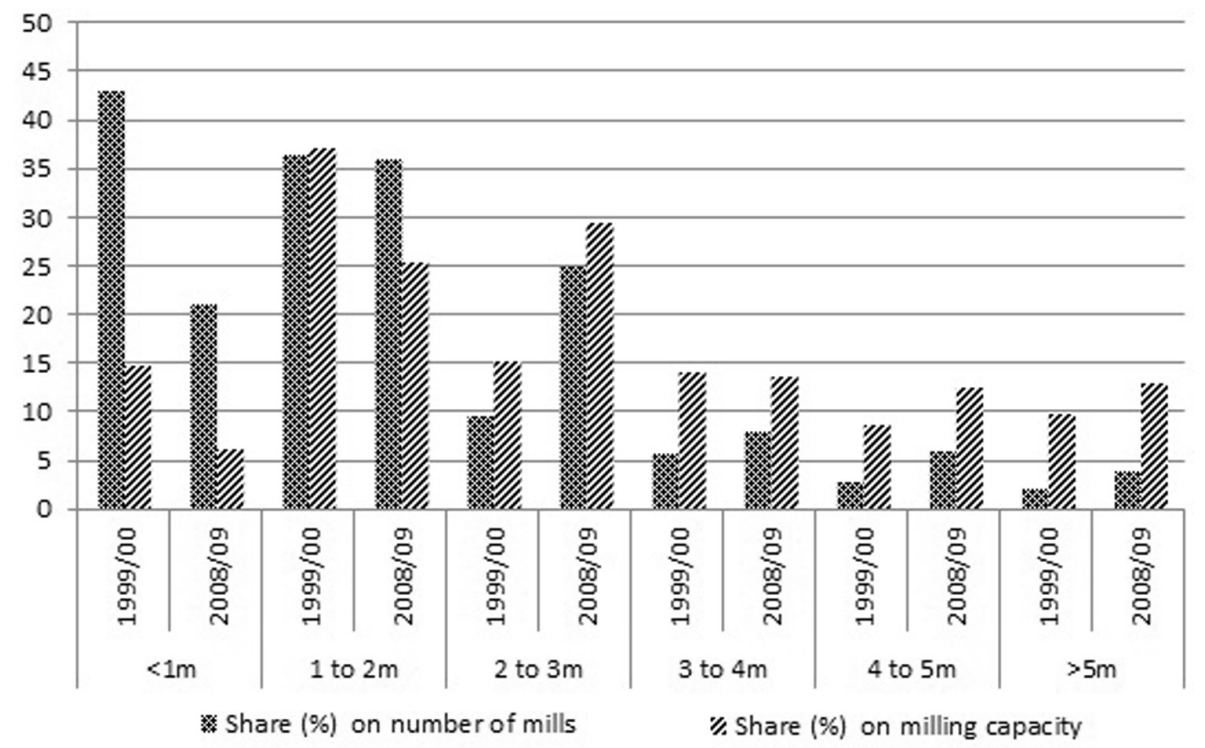

\footnotetext{
Graph 2 - Milling participations (\%) in harvest 99/00 and 08/09 considering the size of mill

Source: Castro et al. (2010).
} 
In an analysis of the share plants hold in the state's milling of sugarcane, Castro et al. (2010) also found growth in the share of plants milling 2 to 3 million tons per harvest in the state (see table 2 ), raising the share of plants with this milling capacity from $15.32 \%$ in the $99 / 00$ harvest to $29.43 \%$ in the $08 / 09$ harvest. In addition, a drop from $14.81 \%$ to $6.06 \%$ in share was found for plants with milling capacities up to 1 million tons per harvest.

Specialists 7 point to the following reasons to explain the gain in scale of the plants: gains in specialization, bargaining power when purchasing supplies, access to better financing conditions and the law of large numbers. These elements were presented as the key factors for the scale growth of sugar mills during the early Alcohol National Program (Proálcool) expansion during the 70s and 80s (SZMRECSÁNYI, 1979; MANOEL, 1985). These are all highly relevant in explaining the decline in units of up to 1 million ton, considering the technical indivisibility of equipment and the geometric economies as not very relevant.

When considering gains from specialization, it is evident that new industrial plants have a high degree of automation and less human interference in the process, lessening the need for manpower. Furthermore, the change caused by professionalization of industrial management at these new units stands out, especially with the entry of new foreign groups. In the past, these units executed various services on their own, especially maintenance services. This caused them to have a larger staff with various abilities that were used at different stages of production. Today, there is a significant trend towards outsourcing of services and there has been a migration of manpower from industrial units to manufacturers and suppliers.

It is worth mentioning the increased power of mills to negotiate with suppliers as a result of the gain in scale. The economic groups are able to negotiate supplies for their different production units. The same advantage occurs for plants with a greater scale. In some regions, the smaller and less capitalized economic groups were unable to withstand the sugarcane price war and they ended up dramatically reducing capacity, losing profits, and eventually going out of business. Easier access to loans and financing by large groups is also considered a disadvantage of smaller-sized plants. The entry of industrial giants from other segments, such as Shell, into the sugar and alcohol industry, is also worth noting. It is much easier for them to leverage resources with financial institution, indicating a real gain in scale at the corporate level in this case.

Finally, the law of large numbers is highlighted as being responsible for the advantage of not only the larger industrial units, but also of those groups with more plants, since they are able to globally negotiate service provider contracts with thirdparty companies.

Another important point is that many smaller units do not have a professionalized and well-structured administration, causing them to make mistakes when managing industrial and agricultural resources. Lack of planning and strategy has made these units more sensitive to price fluctuations, leading many to accumulate debt that, in some cases, they are unable to pay. Therefore, many smaller industrial units have no planning for expansion, making future growth and survival unfeasible.

On the other hand, the rising price of sugarcane and other plant supplies were considered to be highly relevant in deciding the size of the plant milling capacity and the location chosen for it. When deciding on the scale of milling and location of the plant, the region's potential is assessed from the standpoint of planting area available

\footnotetext{
7 In order to complement the information collected by literature review, this research contacted two specialists working with projects to expand and build new plants. They answered a questionnaire considering the strategies by mills when deciding to expand their milling capacity.
} 
(both owned by external suppliers or land that can be purchased for mills to produce their own cane), potential competitors for cane (other mills), size and organization of the main sugarcane suppliers, dependence on one or more landowners, and other factors. In most cases, prior to starting an industrial project study, agricultural partners are already aligned; in other words, there is a "demarcation of territory" that results in long-term land lease contracts for supplying cane. There is no general rule for how agricultural processes are shaped; yet, in general, partnerships are discussed with the region's largest landowners. The company tends to purchase part of the land if available.

\section{Site and time specificity: a limit to a plant growth}

There are few in-depth analyses on the economies and diseconomies of scale for Brazilian sugar and alcohol plants. Among the studies done on the subject, Baccarin et al. (2009) has explained how the distance between the sugarcane cropland and the processing plant affects the mills' costs.

Sugarcane presents a low value-weight ratio, which implies that sugarcane farms cannot be very far from the plants and distilleries in order to be economically viable. Even with the technological evolution in sugarcane transport, shown by the use of double or triple trailer semi-trailer trucks, which has lowered the cost per kilometer traveled, the average distance from the sugarcane fields to industrial processing in the 2007/08 harvest was under 23.2 kilometers, and $86.6 \%$ of these fields in the Central-South region of Brazil were in a 40 kilometer radius from the agro-industry (BACCARIN et al., 2009).

A study developed by SENAR (National Rural Learning Service) showed that "in the traditional sugarcane producing regions, a standard economic distance of 20 kilometers is considered by mills. This distance is determined by the high cost of transporting sugarcane to the industrial unit and is one of the decisive factors in the field's profitability. For example: a producer that has to move sugarcane for processing to an industrial unit that is $50 \mathrm{Km}$ away from the farm will have an added production cost of $13 \%$. While being $5 \mathrm{Km}$ away from the industrial unit will have a $7 \%$ lower cost than if a field is $20 \mathrm{Km}$ away from a unit" (SENAR, 2007).

According to surveys done by CONAB (National Food Supply Company), the extraordinary increase in the scale of processing can be found, as the increasingly greater distance needed to obtain raw material. Table 1 summarizes some interesting elements found for the state of São Paulo, where there is a greater concentration among processing units.

\section{Table 1 - Sao Paulo: Indicators of Milling Scale and} Distance for Supplying Raw Material

\begin{tabular}{cccc}
\hline & $\begin{array}{c}\mathbf{2 0 0 7 - 0 8} \\
\text { Harvest }\end{array}$ & $\begin{array}{c}\mathbf{2 0 0 8 - 0 9} \\
\text { Harvest }\end{array}$ & $\begin{array}{c}\mathbf{2 0 0 9 - 1 0} \\
\text { Harvest }\end{array}$ \\
\hline $\begin{array}{c}\text { Average Nominal Capacity for Milling } \\
\text { (ton/day) }\end{array}$ & 10,322 & 10,527 & 11,364 \\
\hline $\begin{array}{c}\text { Average Distance to deliver sugarcane } \\
(\mathrm{km})\end{array}$ & 23.87 & 25.1 & 25.65 \\
\hline $\begin{array}{c}\text { Percentage of sugarcane with average } \\
\text { Distance over 40 km }\end{array}$ & $15.2 \%$ & $16.9 \%$ & $18.4 \%$ \\
\hline
\end{tabular}

Source: CONAB (2008, 2010, 2012). 
The data in Table 1 brings evidence about the growth in the scale of milling and the distance traveled to receive raw material. Unfortunately, the most recent CONAB survey is for 2009-10; yet, we are able to state that these distances have grown with each harvest, given the greater concentration of plants and distilleries in the same region and given that the scales practiced are far above 1 million hectares.

It is also worth mentioning that the milling of 1 million tons of sugarcane per harvest would require a continual and compact area of raw material within a straight line radius of around $7 \mathrm{~km}$, which shows that the increased scale found is directly proportional to the increased distance in the cutting of the sugarcane. This site specificity is intensified by a times specificity, given that after the harvest, the sugarcane must be processed as quickly as possible (within 48 hours), so as not to seriously compromise its industrial yield in sugar and alcohol production. Various factors affect the speed at which the quality of sugarcane deteriorates due to the sucrose inversion process, such as environmental conditions (temperature and humidity), for instance. Processing of sugarcane that is already undergoing the sucrose inversion process results in a reduction of total recoverable sugar (TRS).In other words, because it is not stored, there must be substantial synchronicity in the timing between harvest and industrial processing of sugarcane.

Together, the site-and-time-based specificities result in the need for nearby lands to grow sugarcane as a very relevant source of plant competitiveness. Therefore, the availability of lands means that there is a limitation to plant growth. In regions with higher numbers of plants, this competition for sugarcane results in higher costs, which can be seen in the difference in leasing prices in regions near plants.

So, it is important to reflect on the impact of economies of scale and access to raw materials in entry barriers, the efficiency of sugarcane sector in Brazil, and its social impacts. As industries need sugarcane to produce sugar and alcohol, it is necessary to ensure the supply and provide an amount according to the current production capacity, as well as to meet the mill's expansion plans in the future. Restricting access to sugarcane is a major source of loss of competitiveness, as the company will operate with idle capacity. In this sense, the strategies of buying cropland or longterm leasing have become essential to guarantee its supply network and to preserve the competitiveness in the future.

\section{MATERIAL AND METHODS}

Maps were created based on the concept of areas of influence, which presupposes analysis of a certain phenomenon using procedures geared towards spatial distribution of central points and their spatial ranges (BUZAI; BAXENDALE, 2006). The location of sugar and alcohol plants (central points) was determined based on creation of a georeferenced database, which was based on information from the Ministry of Agriculture, Livestock and Supply (MAPA) regarding plants in operation in the state of São Paulo.

For each plant, the ratio between the milling capacity and the area planted with sugarcane that would be necessary to meet this capacity was used as a parameter of spatial range:

$$
\text { Production (ton) }=\text { Area (ha). Productivity }\left(\frac{\text { ton }}{\text { ha }}\right)
$$

$$
\operatorname{Area}(\text { ha })=\pi \cdot \text { Radius }^{2} \text { (meters) }
$$


Productivity of 70 tons per hectare was considered a state average. This being the case, 14,280 planted hectares would be necessary to produce 1 million tons of sugarcane (without considering the renewal of sugarcane plantation). Converted into a circular area, this results in a radius of 6,930 meters. Thus, the calculation shows that in order to meet a milling capacity of 1 million tons, a radius of approximately $7 \mathrm{~km}$ of area planted with sugarcane is needed. The spatial units considered were regions of São Paulo state (Map 1), which allowed for a comparative analysis between different socio-economic conditions in these regions and the influence these different environments have on mill strategies.

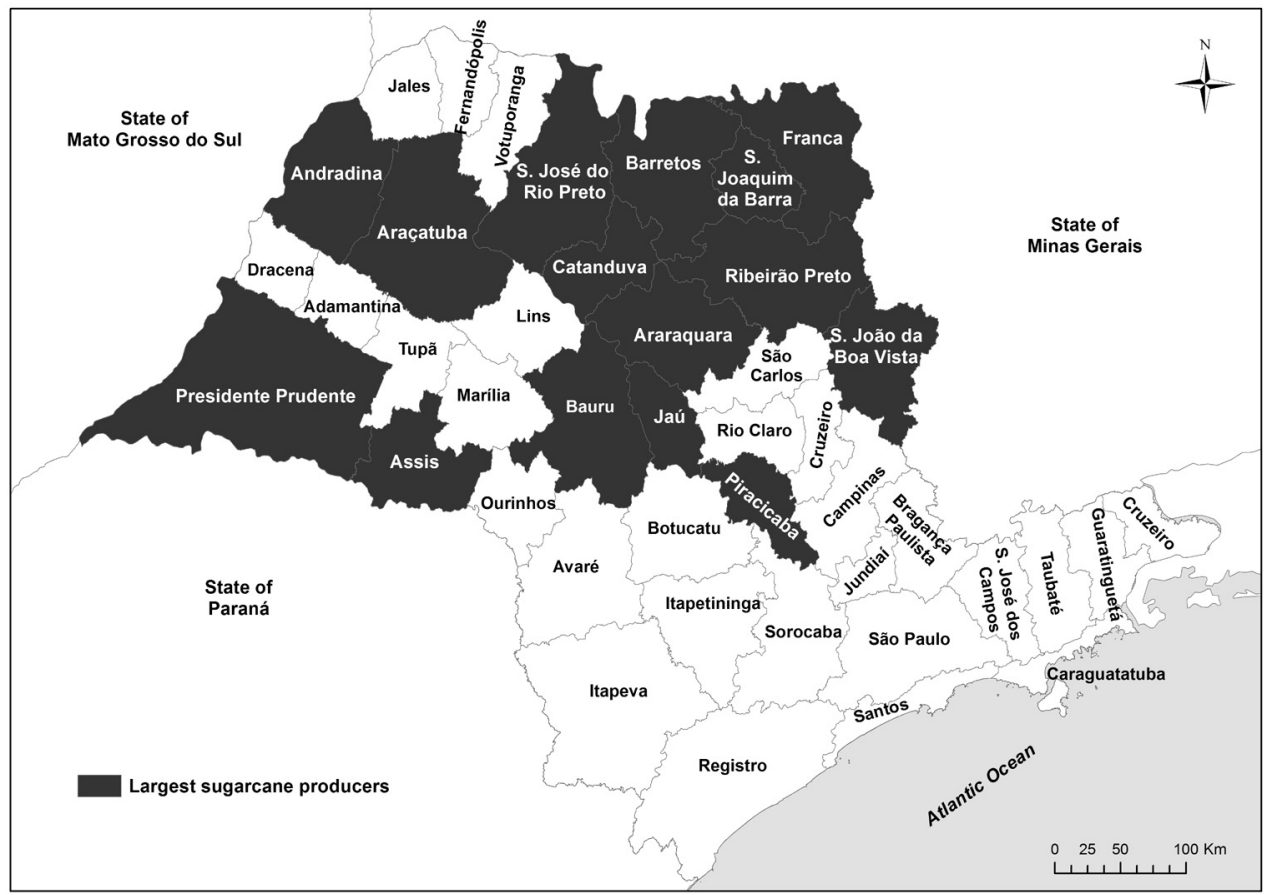

Map 1 -Regions in the state of São Paulo

Source: Based on Graph 1.

Moreover, geo-referenced data were used for the area planted with sugarcane in 2010, provided by CANASAT in order to assess the location of plants and the supply of raw material. Data and information were organized into a Geographic Information System (GIS) that allowed for creating thematic maps showing: (i) location of plants, installed milling capacity and area planted with sugarcane; (ii) competition between plants based on areas of influence, using the proposed radius of $7 \mathrm{~km} / 1$ million tons of installed capacity, considering overlapping of areas showing regions with more/less competition for raw material; and (iii) the Region of Ribeirão Preto. 


\section{Numerical Analysis}

This analysis started by choosing 15 regions in São Paulo state, considering the ones which higher share of sugarcane on the agricultural area. Next, it was estimated the installed milling capacity of each mill, using data from the Anuário da Cana 2013 (PROCANA, 2013). In cases that information about a specific mill was not available on this publication; additional data was collected from the firm's websites or by phone contact. When this information was not available in all the mentioned channels, the mill was excluded from the analysis. In these cases, the milling capacity is underestimated for the region, since some mills were not included (e.g. Ribeirão Preto had 3 mills excluded; São José do Rio Preto had 2 mills excluded; Presidente Prudente e Araçatuba had 1 mill excluded). In other cases, the whole region was excluded due to the lack of information regarding the milling capacity (e.g. Bauru).

The second step was to sum up the milling capacity of each mill in order to find the installed milling capacity for each region. Since this information was not standardized (in some cases the capacity was informed by day, in others by month and in some cases, by year), we chose to transform all data to annual milling capacity, supposing that each year has 242 days of milling operations (this data was obtained from CONAB report). The third step was to estimate the average yield for sugarcane production in each region, considering the last 12 harvests based on cultivated sugarcane, according to Brazilian Institute of Geography and Statistics (IBGE). Step number four was to calculate the radium necessary to produce the sugarcane necessary to supply the installed milling capacity. This calculus was done by equation 1 , and considered each region yield obtained in step 3 .

Finally, the necessary area to supply the sugarcane for the installed milling capacity was subtracted from the effective area planted in 2012. If the planted area was shorter than the necessary area, the region would have a lack of sugarcane for the mills to operate in their optimal capacity.

\section{RESULTS AND DISCUSSION}

As a result of the study, a map was initially created showing the location of plants within the state and their milling capacity (see figure 2). Note the greater concentration of plants considered to be large, with over 5 million tons per harvest, is found in the traditional sugarcane farming region of Ribeirão Preto and in the regions neighboring Araraquara, S. Joaquim da Barra, Barretos and Franca.

As shown in map 2, a large agglomeration of mid-sized (between 2 and 3 million tons harvested) plants can be found in the so-called expanding regions, such as Araçatuba and Presidente Prudente. This increasing expansion of the sugarcane frontier in the state of São Paulo partly explains the considerable rise in average scale, given that the current technological stage is already being considered when building new units in these regions.It's likely that these units could grow in the future if the sugar and ethanol market proves to be more favorable and there is sugarcane available to support the growth of these plants. 


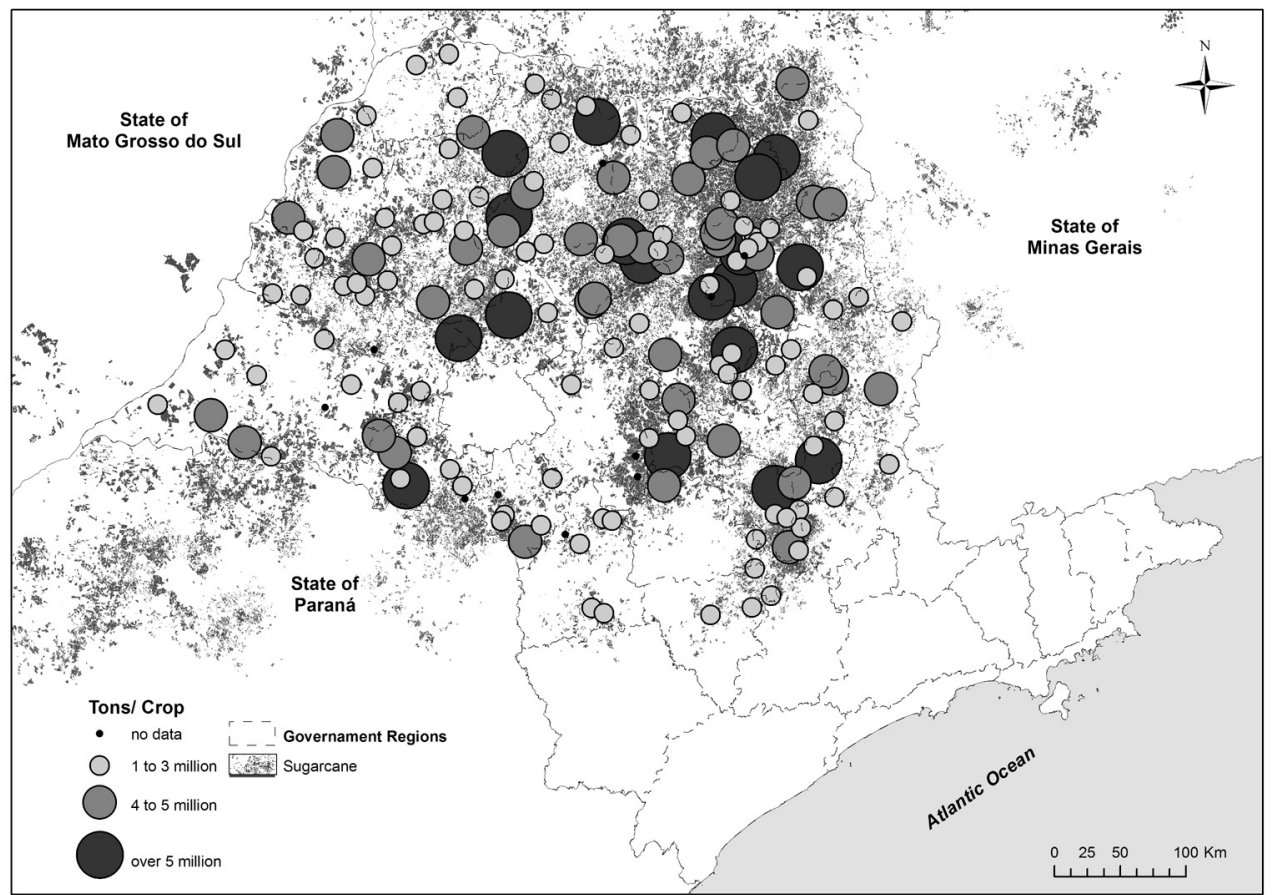

Map 2 - Location of plants by size in the state of São Paulo

Source: elaborated by the authors using data from MAPA, CANASAT and Annual Sugarcane Data Report.

Considering the size of the plants, a map was created (Map 3) showing the competition for sugarcane in the state of São Paulo. Competition for sugarcane in other regions of the state has also been noted, although it is less intense.

It is interesting to note the substantial competition for sugarcane in the traditional sugarcane producing region of Ribeirão Preto and its neighboring area (see Map 4).The greatest competition for sugarcane in this region is consistent with the higher milling capacity found at the plants installed there.

In other regions, like Barretos, S. Joaquim da Barra, Andradina, Araçatuba and S. Jose do Rio Preto there is still available lands in order to supply the total milling capacity installed, even though this process would surely compromise other important agriculture chains by expanding sugarcane on livestock and grains areas. In order to supply the cane demand, the share from the agricultural area occupied with cane would raise from $75,2 \%$ to $82 \%$ in S. Joaquim da Barra, from 57 to $66 \%$ in Barretos, from $33,6 \%$ to $66 \%$ in Andradina. S. Jose do Rio Preto presents the most "comfortable" situation, and the necessary sugarcane would not go beyond $50 \%$ of the agricultural area. 


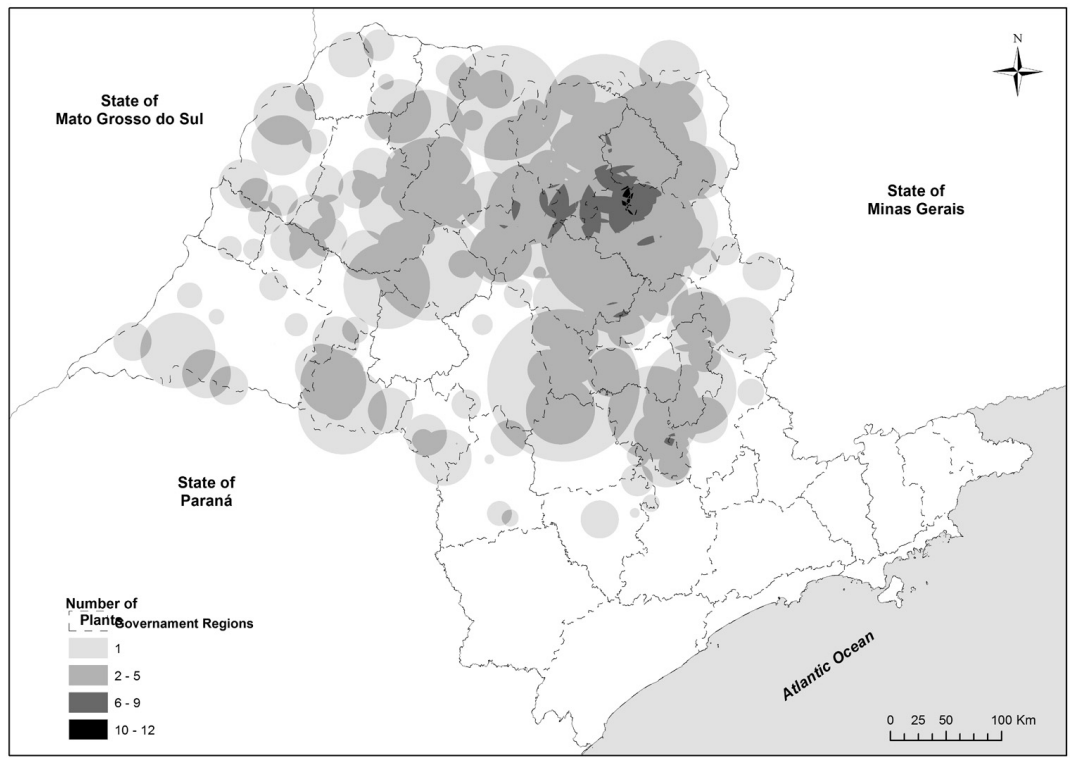

Map 3 - Competition for sugarcane in the state of São Paulo Source: Elaborated by the authors using data from MAPA and Annual Sugarcane Data Report.

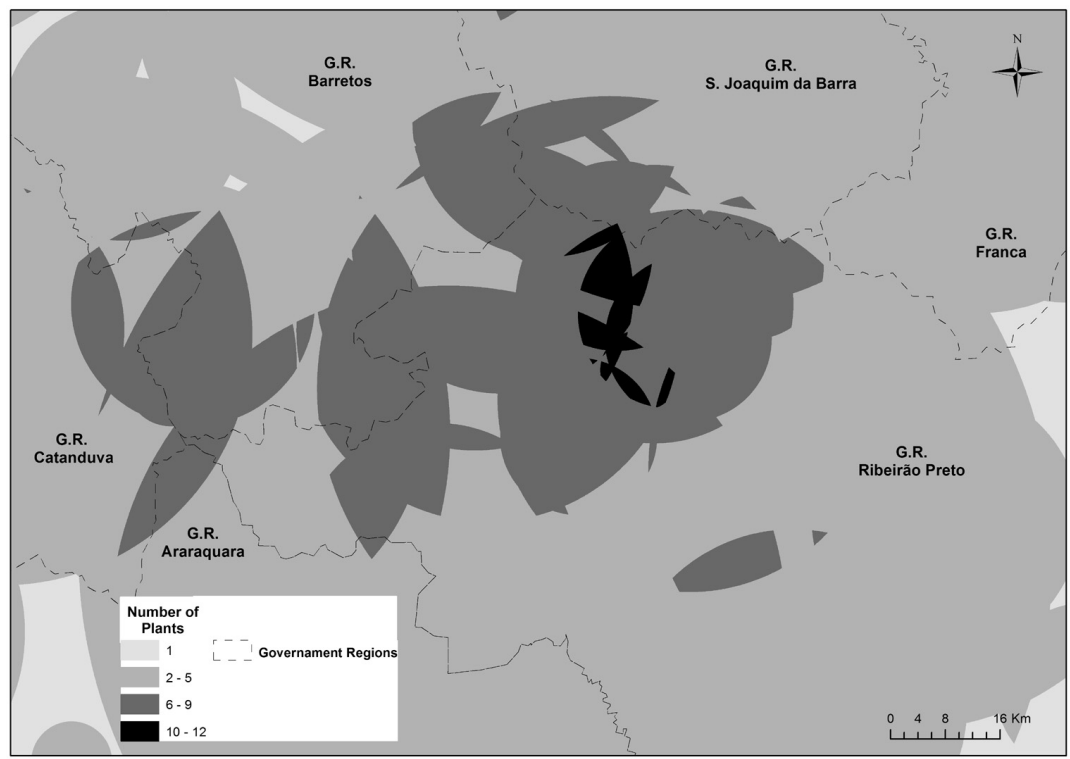

Map 4 - Competition for sugarcane in the region of Ribeirão Preto and its neighboring regions Source: Elaborated by the authors using on data from MAPA and Annual Sugarcane Data Report. 
In Presidente Prudente, Araraquara, Franca and São João da Boa Vista, the area planted with sugarcane is already enough to supply the installed milling capacity. Even though these numbers can be useful to illustrate the magnitude of the supply gap in the main sugarcane regions of São Paulo state, there are limitations in these comparative exercises. Evidently, if plants with a high installed capacity are near frontier regions, it would be possible to extend production to the neighboring region, although this could represent a spike in logistical costs.

At any rate, the impact of this deficit in the short term could be the idleness of the plants, which would function at below their milling capacity. Alternatively, mills could procure sugarcane in more distant regions. Both cases result in more cost to companies. In the long term, this could lead to two development paths: an increase in farmed area used for sugarcane, which could be difficult due to the already high share of sugarcane in arable areas; or an industrial concentration process in the coming years, with stronger economic groups acquiring the smaller plants.

According to Ferreira and Alves (2009), historical evidence ${ }^{8}$ also indicates a possible spatial reorganization of the land São Paulo state, wherein competition for sugarcane would force companies to begin a process of mergers and acquisitions, concentrated on production of sugar and alcohol. In this process, even efficient plants could be acquired and, in some cases de-activated, since the buyers would be mainly interested in the sugarcane crops owned by the acquired company. As an example of this process, the acquisition of the Santa Luiza plant, which has a milling capacity of 1.6 million tons per harvest, by a holding called Etanol Participações is mentioned. This holding is comprised of three economic groups: São Martinho, Cosan and Santa Cruz. Its main asset was identified as the ability to mechanize $90 \%$ of its area and all of the sugarcane available within a 14 kilometer radius.

\footnotetext{
8 Ferreira et al. (2009) conducted a documentary research on public policies $\%$ at the federal level and the state of São Paulo \% to increase the competitiveness of sugarcane sector from the late 1960 s to the $1980 \mathrm{~s}$. By implementing competitiveness, it was planned to increase the scale of production in the mills, and an attempt to regulate the distance between the plants to avoid competition for sugarcane. In the 1990s, a gradual change has started in the role of the State in the Brazilian economy, abandoning the induction character of development to become a market regulator. In this matter, the consumer rights are ensured, the industry monopoly power is avoided, and standardizing the products to ensure human, animal, plant, and environment health. The change in the role of the State in the Brazilian economy discourages the development of public plans to coordinate private investments and to increase the sector's competitiveness.
} 


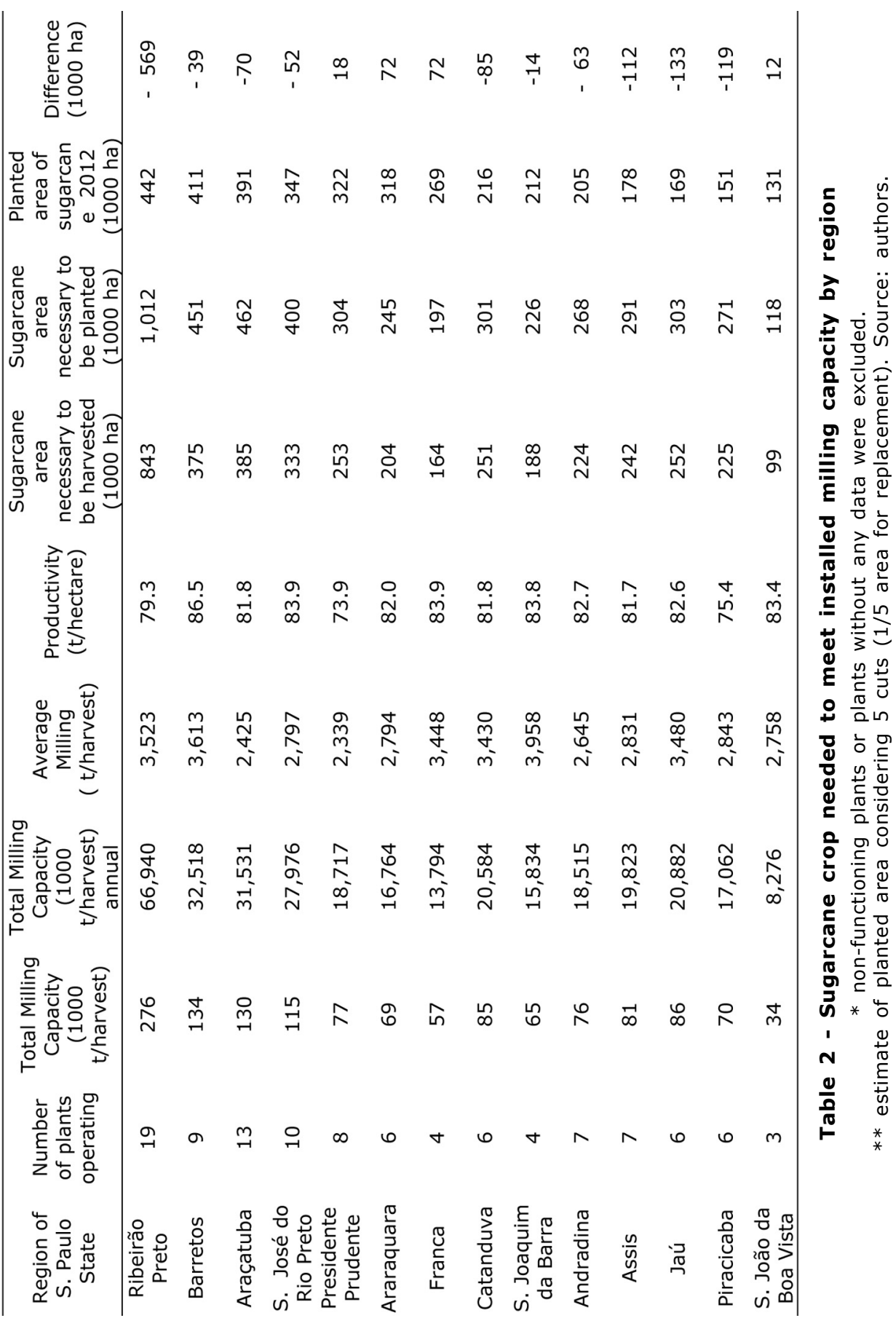




\section{FINAL CONSIDERATIONS}

In the 1940s, the creation of compatibility between agricultural production and industrial processing in the sugar and alcohol industry had already begun to be controlled by the Brazilian government through a series of laws known as the Sugarcane Farms Act (Estatuto da Lavoura Canavieira). This regulatory framework created under the auspices of the IAA allowed this agency to coordinate and control areas of expansion, trade relations between suppliers and industries and the amount produced. Nevertheless, not even this intervention prevented periods of overproduction and a drop in prices. A high concentration was also found in this market around large, family-based economic groups that continued to expand their political power and influence over the government.

In 1990, the IAA was closed; at the same time but for a different reason, there was a notable jump in growth in sugarcane agro-industry production. This growth was marked by the entry of foreign groups and capital from Brazilian industries, which led to a relative de-nationalization of the industry.

In this process, the size of facilities also grew, especially in the new areas. Thus, a greater industrial concentration was seen, with a decline in both the number of plants and the share of milling in the state at plants considered "small" (milling capacity of 1 million tons per harvest) between the 1999/2000 and 2008/2009 harvests. There was also notably a spike in the number of 2 and 3-million ton plants and relative stability at large plants with capacities of over 5 million tons. Therefore, we can draw the conclusion that the scale of milling chosen at most of the new projects was between 2 and 3 million tons. Exploratory research with industry specialists shows that the process of growth at plants is "modular," taking place by phases, due to the period of development of the sugarcane fields and better distribution of investments over time. Soon, these plants will be able to expand in the coming years.

An analysis of maps shows that in certain regions of the state of São Paulo, there is a large concentration of production units with a high scale of milling. This feature leads to greater competition for sugarcane, which results in effects on production costs, as well as an intensification of negative externalities, such as increased monoculture, concentration of lands and elimination of the sugarcane supplier independent farmer, as established by the Sugarcane Farms Statute. Data demonstrate that installed milling capacity is very superior than the potential sugarcane production in the most important production regions in São Paulo state, like Ribeirão Preto and Piracicaba. This situation indicates a tougher competition for raw material by mills in these regions.

Using the region of Ribeirão Preto as an example, in order to use $100 \%$ of the installed capacity, the area planted with sugarcane would have to practically double in future harvests. Although the supply areas can extend beyond regional borders (with obvious additional logistics costs), it seems clear that there would be a tendency for sugarcane to put pressure on other crops and on local livestock to cede new areas. Competition for sugarcane should also accelerate the process of mergers and acquisitions of plants in future years. With access to a greater amount of sugarcane, economic groups will be able to cut costs of acquiring suppliers and the growth in the scale of the plants.

This paper mapped the location of sugar and ethanol plants, their milling capacities and the competition for sugarcane in the areas where they are located. In the future, this process of expansion and competition for sugarcane could be better understood by including research considering the insights and views of mill representatives, allowing 
for a better understanding of the following aspects: (i) Whether plants that currently have a milling capacity of 2 to 3 million tons per harvest were intentionally designed to remain this size or whether they were planned in a "modular" scheme, to expand milling capacity in the future. (ii) What are the main factors considered for choosing the size of milling capacity for plants and their location? (iii) What are the effects on the costs of plants as a result of competition for sugarcane insofar as the following factors are concerned: idleness of the industrial plant because it lacks access to the sugarcane needed to supply its full capacity; high transportation costs because of the need to find this supply within a greater distance? (iv) Which strategies do plants use to reduce competition for sugarcane?

\section{REFERENCES}

ALVES, D.; FERNANDO, W.; FRIEDRICH, B.; RUDORFF, T.; SUGAWARA, L. M. Expansão da cana-de-açúcar no Estado de São Paulo: safras 2003/2004 a 2008/2009. SIMPÓSIO BRASILEIRO DE SENSORIAMENTO REMOTO, 14, Natal, Anais..., 2009

BACCARIN, J. G.; GEBARA, J. J.; FACTORE, C. O. Concentração e Integração vertical do setor sucroalcooleiro no centro-sul do Brasil, entre 2000 e 2007. Informações Econômicas, São Paulo, v. 39, n. 3, p. 17-28, 2009.

BAIN, J.S. Industrial organisation. New York: Wiley, 1959.

BUZAI, G.D.; BAXENDALE, C.A. Análisis socio espacial con sistemas de información geográfica. Buenos Aires: Lugar Editorial GEPAMA, 2006.

CASTRO, N. C.; DANTAS, G.A.; BRANDÃO, R.A Dinâmica estrutural do setor sucroenergético como elemento indutor de investimentos em bioeletricidade. In: CONGRESSO SOBRE GERAÇÃO DISTRIBUÍDA E ENERGIA (AGRENER), Campinas. Anais..., p. 1-9, 2010.

CONAB - COMPANHiA nACIONAL DE ABASTECIMENTO. Perfil do setor do açúcar e do álcool no Brasil, situação observada em novembro de 2007. Brasilia: April 2008. Available at: http://www.conab.gov.br/conabweb/download/safra/perfil.pdf CONAB - COMPANHIA NACIONAL DE ABASTECIMENTO. Perfil do setor do açúcar e do álcool no Brasil, safra 2008/09. Brasilia: May 2009. Available at: http:// www.agricultura.gov.br/arq_editor/file/Desenvolvimento_Sustentavel/Agroenergia/ estatisticas/producao/Perfil_Sucroalcooleiro_2008_09_versao_publicada.pdfHYPERLINK "http://www.agricultura.gov.br/arq_editor/file/Desenvolvimento_Sustentavel/ Agroenergia/estatisticas/producao/Perfil_Sucroalcooleiro_2008_09_versao_ publicada.pdf" $\backslash \mathrm{h}$

CONAB - COMPANHIA NACIONAL DE ABASTECIMENTO. Perfil do setor do açúcar e do álcool no Brasil, safra 2011/12. Brasilia: May 2012. Available at: http:// www.udop.com.br/download/estatistica/setor_sucroenergetico/ 2009a10_perfil_setor_acucar_alcool_conab.pdfHYPERLINK "http://www.udop.com.br/ d o w n lo a d / e stat is t i c a / s e tor_sucroenergetico/ 2009a10_perfil_setor_acucar_alcool_conab.pdf" \h

CORREA, V. H. Expansão recente da produção agropecuária no Centro-Oeste: uma análise do impacto ambiental de desmatamento do padrão itinerante das produções de soja, cana-de-açúcar e pecuária bovina. 2013. Ph.D. Thesis. IE - UNICAMP, Campinas, 2013. 
FERREIRA, E. R.; ALVES, F. D. ; RUAS, D. G. G. Organização espacial da cana-deaçúcar no estado de São Paulo: uma análise evolutiva. In: FERREIRA, D.A.O.; FERREIRA, E.R. (Org.). Estudos agrários: conceitos e práticas. Rio Claro: Ed. da pós-graduação em Geografia/IGCE/UNESP, p. 199-215, 2009.

IBGE - Instituto Brasileiro de Geografia e Estatística. Pesquisa Agrícola Municipal, 2011. Available at: http://www.sidra.ibge.gov.br/access in 12/2012.

KUPFER, D. ; HASENCLEVER, L. Economia industrial: Fundamentos Téoricos e Práticas no Brasil. Rio de Janeiro: Ed. Campus, 2002.

MACEDO, F. S. A reestruturação do setor sucroenergético no Brasil uma análise do período entre 2005 e 2011. Dissertation (Agroenergy). EESP-FGV, 2011.

$M A N O E L, A$. Política agrícola, eficiência e concentração na agricultura brasileira: um estudo do setor canavieiro paulista. Ph.D. Thesis. FEA-USP, São Paulo, 1985.

PENROSE, E. T. Teoria del crecimiento de la firma. Madrid: Aguilar, 1962.

PEROSA, B. B. Mercado internacional de biocombustíiveis: a emergência da governança socioambiental. Agroanalysis, Maio, p. 25-27, 2012.

PEROSA, B. B.; FREDO, C. E.; BELIK, W. Dinâmica econômica e emprego nas regiões canavieiras do estado de São Paulo. In: BAENINGER, R.; ZULLO Jr.; AIDAR, T.; PERES, R. G. (Org.). Por dentro do Estado de São Paulo - Regiões Canavieiras. 1st. ed. Campinas: Unicamp, 2013, v. 1, p. 41-63.

PINDYCK, R.S.; RUBINFELD, D.L. Microeconomia. 5th. ed. São Paulo: Prentice Hall, 2002.

PROCANA. Anuário da cana 2013 (Brazilian sugar and ethanol guide 2013). Ribeirão Preto.Editora ProCana.2011

SENAR - SERVIÇO NACIONAL DE ACOMPANHAMENTO RURAL. Cana-de-açúcar: orientações para o setor canavieiro: ambiental, fundiário e contratos. Brasília: CNA SENAR, 2007.

SZMRECSÁNYI, T. O planejamento da agroindústria canavieira do Brasil (193075). São Paulo: Hucitec, 1979.

STEINDL, J. Maturity and stagnation in American capitalism. Oxford: Basil Blackwell, 1952, reprint by Monthly Review Press, 1976

UNICA. Unicadata. Produção. São Paulo Brasil. Available at: www.unicadata.com.br accessin: 05/mai2013)

VIAN, C. E.; BELIK, W. Os desafios para a reestruturação do complexo agroindustrial canavieiro do Centro-Sul. ANPEC ECONOMIA, Niterói (RJ), v. 4, n. 1, p. 153-194, Jan. /Jun. 2003

Recebido em fevereiro de 2015

Revisado em julho de 2016

Aceito em julho de 2016 